\title{
ZADOVOLJSTVO STUDENATA TEHNIČKOG VELEUČILIŠTA U ZAGREBU PROVOĐENJEM ONLINE NASTAVE
}

\author{
mr. sc. Lucija Bačić, v. pred. \\ Tehničko veleučilište u Zagrebu \\ Vrbik 8, 10 000, Zagreb, Hrvatska \\ Telefon: +385915364727, e-mail: lucija.bacic@tvz.hr \\ Marija Krstinić, pred. \\ Tehničko veleučilište u Zagrebu \\ Vrbik 8, 10 000, Zagreb, Hrvatska \\ Telefon: +385915336380, e-mail: marija.krstinic@tvz.hr
}

\section{SAŽETAK}

Epidemija uzrokovana virusom Covid-19 aktualizirala je potrebu za otkrivanjem različitih metoda kao i procjenom uspješnosti poučavanja "na daljinu“. Nastavnici i studenti diljem svijeta su se suočili s možda i najvećim izazovom dosad, u kratkom vremenu se prilagoditi dostupnim platformama i jednako tako prihvatiti kako prednosti tako i mane virtualne nastave. Ova epidemija je zapravo i proširila jaz između onih koji mogu pristupiti mogućnostima digitalnog učenja i onih koji su isključeni jer se nisu svi jednako uspješno prilagodili. Isto tako se mora naglasiti da dobro iskustvo online učenja nije nužno vezano uz tehnologiju koju izabiremo, već uz način na koji se nastavnici i studenti posvete tom podučavanju, pogotovo kada je riječ o učenju stranog jezika. U ovom radu provedeno je istraživanje na uzorku od 120 redovnih i izvanrednih studenata 2. godine Strojarskog odjela Tehničkog veleučilišta u Zagrebu, u travnju i svibnju 2020. godine. Ciljevi istraživanja su pokazati stupanj zadovoljstva, odnosno nezadovoljstva studenata Tehničkog veleučilišta kao i utvrditi stupanj težine savladavanja stranog jezika online nastavom. Istraživanje je provedeno anketnim upitnikom na temelju kojeg će se izračunom relativnih frekvencija utvrditi navedeni ciljevi.

Ključne riječi: online nastava; klasična nastava; učenje stranog jezika; motivacija 


\section{UVOD}

Izbijanje i brzo širenje pandemije COVID 19 rezultiralo je diljem svijeta brojnim poremećajima koji su trajno obilježili i promijenili sve segmente dosadašnjeg načina života, uključujući i mogućnosti obrazovanja, osposobljenja i mobilnost svih sudionika obrazovnih procesa. lako je unatrag nekoliko godina zabilježen rast i usvajanje obrazovnih tehnologija (Edtech), značajni porast primjene inovacija u obrazovanju upotrebom aplikacija, software-a i ostalih alata uslijedio je globalnim zatvaranjem škola, kada se bez dovoljnih priprema u vrlo kratkom vremenu i velikim angažmanom, u prvom redu nastavnika, poučavanje nastavilo izvoditi na daljinu (EC, 2020).

E-učenjem osigurao se kontinuitet za većinu aktivnosti i različite svrhe osposobljavanja i obrazovanja što su omogućile brojne digitalne platforme, u prvom redu povezujući jedne s drugima bez obzira na mjesto i udaljenost, omogućujući pristup i retenciju informacija svima kojima je to potrebno i na fleksibilan način podržavajući kontinuirani profesionalni razvoj i osobno usavršavanje nastavnika (WEF, 2020). Tako se i učenje stranih jezika, u ovom novom normalnom okruženju, našlo pred izazovom prilagodbe nastavnika i učenika.

Cilj rada je istražiti stupanj zadovoljstva, odnosno nezadovoljstva online nastavom studenata Tehničkog veleučilišta s obzirom na neočekivanu nastalu situaciju u kojoj su se u iznimno kratkom vremenu i nastavnici i studenti morali prilagoditi novim metodama i dostupnim platformama kako bi se obrazovni proces nastavio unutar dosadašnjih standarda kvalitete. Istraživanjem su također identificirane prednosti i mane virtualne nastave kao i težina savladavanja znanja iz predmeta stranih jezika.

\section{MOTIVACIJA STUDENATA U ONLINE NASTAVI}

Motivacija koja je i do sada predstavljala jedan od afektivnih čimbenika, u novonastalim uvjetima i kada je riječ o učenju stranih jezika, još značajnije potiče volju i spremnost studenata za usvajanje znanja. Poticanje zainteresiranosti i osjećaja inkluzivnosti u nastavi uglavnom ovisi o angažmanu nastavnika, a kada se to odvija u bitno drugačijim uvjetima učenja na daljinu može imati i prednosti i nedostatke, međutim i od ranije potreba za povezanošću i komunikacijom kroz brojne društvene mreže, učenje stranih jezika učinila je nešto prioritetnije u odnosu na sve drugo. Međutim, s obzirom na drugačije uvjete održavanja online nastave u odnosu na klasičnu, mijenja se i konzistentnost i struktura. To zahtjeva veću fleksibilnost u pristupu, kreiranju i poučavanju nastavnog sadržaja te poticanje sudjelovanja i kreativnost u komunikaciji, kako bi se pokazalo razumijevanje $s$ trenutnom situacijom, ohrabrilo i potaknuo veći interes studenata. Do sada su istraživanja uglavnom ukazivala na pogodnosti i učinkovitost online učenja i oslobađanje obrazovnog potencijala u odnosu na tradicionalni način održavanja nastave u učionicama. Većina usluga i alata platformi su besplatne. Za učenje je potrebno manje vremena jer dostupnost objavljenih materijala i informacija omogućuje usvajanje novih znanja prema individualnim sposobnostima i tempu, što bitno povećava brzinu i učinkovitost u usvajanju novih znanja. Poučavanje putem digitalnih platformi odmak je i moguće značajan iskorak za stvaranje učinkovitih metoda obrazovanja koje bi transformirale nastavu i učenje te ubrzalo prijeko potrebne inovacije (ISTE, 2020), čime bi se potaknula prilagodljivost i kritičko razmišljanje, što je u odnosu na tradicionalne ishode učenja, za uspjeh kao i razvoj 
kompetencija u budućnosti puno važnije, ali je i upitno hoće li se pritom povećati ili umanjiti nejednakost, dostupnost i pravednost obrazovanja svima (EDP, 2020). Odgovor na pitanje može li se strani jezik učiti online znatno ovisi i o vjerovanjima nastavnika o tehnologiji i učenju jezika, kao i o motivaciji učenika za takvim učenjem. Nove tehnologije nam omogućavaju da današnja virtualna učionica može preslikati interaktivno iskustvo okruženja licem u lice. Sinkrona komunikacija moguća je putem videokonferencija, putem alata za igre, mogu se vježbati prezentacije vještine, a razvijanje kulturnih kompetencija lako je uz bogatstvo autentičnih sadržaja dostupnih na mreži. Uspjeh internetskog iskustva učenja nije toliko vezan za tehnologiju koju smo odabrali, koliko za način na koji se učitelji i učenici bave njome (EmergingEdTech, 2017). Naše vlastite pretpostavke o načinu stjecanja jezika, naša uvjerenja o vrijednosti asinkrone nasuprot sinkrone komunikacije, naše predrasude o vrstama učenika koji pohađaju jezične tečajeve na mreži, naša sposobnost i motivacija za prilagodbu trenutnom kao i naša pristranost prema određenim metodologijama poučavanja i kako ih treba primijeniti, utječu na način na koji pristupamo dizajniranju internetskih tečajeva. Perspektive i očekivanja učenika temeljena na prošlim iskustvima učenja jednako su važna. Stoga su motivacija i pretpostavke učenika najvažniji za učinkovitost online nastave.

\section{ONLINE UČENJE STRANIH JEZIKA}

Može li se strani jezik učiti u internetskom okruženju ili ne, često je postavljano pitanje posljednjih mjeseci. Zanimljivo je da se obje strane argumenta okreću istom pitanju kako bi oblikovale svoje stavove: Može li trenutna tehnologija u okruženju za učenje na daljinu podržati vrstu angažmana i interakcije učenika za koje se vjeruje da promiču usvajanje jezika ili ne? Sumnja u djelotvornost učenja i usvajanja stranog jezika na daljinu pretpostavlja pogled na internetsko učenje kao na radikalno suprotno i inferiorno od učenja licem u lice. Pretpostavlja se da je glavna suprotnost između oba prostora za učenje priroda komunikacije: najčešće je asinkroni u internetskom tečaju, a sinkroni u tradicionalnom razredu. Ovaj naglasak na komunikaciji kao odlučujućem čimbeniku uspjeha iskustva učenja ima temelj u određenoj teoriji usvajanja jezika i njegovim pedagoškim implikacijama. Ovaj teorijski i pedagoški pristup metodologija je komunikacijskog podučavanja jezika koja najčešće dominira podukom stranih jezika. U ovom se pristupu pretpostavlja da se učenje odvija u smislenoj i svrhovitoj interakciji na ciljnom jeziku. Stjecanje nije proces formiranja navika putem ponavljanja i vježbi, već rezultat sudjelovanja s razumljivim unosom i pregovaranjem značenja u razgovoru s drugim korisnikom jezika. Ciljevi učenja vezani su više uz komunikativne funkcije umjesto gramatičkih tema, a naglasak je na interaktivnim aktivnostima u učionici kao što su igre uloga, otvorene rasprave i intervjui. Temeljna je pretpostavka da učenici trebaju nešto učiniti s jezikom i koristiti svoje jezično znanje u situacijama iz "stvarnog“ svijeta. Kako se često mrežno poučavanje smatra suprotnom poukama licem u lice, ovo gledište također počiva na pretpostavci da polaznici internetskog tečaja ne mogu biti toliko aktivno uključeni u iskustvo učenja kao što bi trebali biti kada pohađaju učionicu tjelesnog. Smatra se da je učenje aktivno, a ne pasivno nastojanje i uvelike ovisi o učenicima koji preuzimaju odgovornost za vlastito učenje. Ispitivanje je li ovaj stupanj uključenosti učenika moguć na internetskim tečajevima jezika otkriva sumnje ne samo u pogledu dostupnosti trenutnih tehnologija, već i u pogledu motivacije učenika 
za pohađanje tečaja jezika putem interneta. Prije 30 godina učila su se gramatička pravila i vježbalo jezik ponavljanjem, pamćenjem rječnika i učenjem glagola. Danas je komunikativna metodologija znatno promijenila način učenja jezika: od učenika se očekuje da razgovaraju, pjevaju i govore na ciljnom jeziku. Za mnoge je učenike ovo ogroman iskorak iz zone udobnosti i oni se često opiru ovoj pedagogiji aktivnog učenja. Kada je njihova motivacija za pohađanje nastave stranog jezika ekstrinzična, tj. kada imaju obvezu učenja stranog jezika, ti studenti mogu preferirati mrežne tečajeve vođeni neutemeljenim uvjerenjem da razgovor i konverzacija na ciljnom jeziku neće biti važan dio tih tečajeva.

\section{EMPIRIJSKO ISTRAŽIVANJE ZADOVOLJSTVA STUDENATA TEHNIČKOG VELEUČILIŠTA PROVOĐENJEM ONLINE NASTAVE}

Istraživanje je provedeno u travnju i svibnju 2020. U istraživanju su sudjelovali redovni i izvanredni studenti ( $\mathrm{N}=120)$ preddiplomskog studija Strojarskog odjela, Tehničkog veleučilišta u Zagrebu.

\subsection{Ciljevi istraživanja}

Ciljevi istraživanja pokazati su stupanj zadovoljstva, odnosno nezadovoljstva studenata Tehničkog veleučilišta kao i utvrditi stupanj težine savladavanja stranog jezika online nastavom.

\subsection{Metodološki okvir i uzorak istraživanja}

Podaci su prikupljeni na uzorku od 120 studenata 2. godine Strojarskog odjela Tehničkog Veleučilišta u Zagrebu pomoću upitnika sastavljenog za potrebe ovog istraživanja, a koji se sastojao od dva dijela. U prvom dijelu ispitanici su odgovarali na pitanja o spolu, godini studija, godinama učenja te doticaju sa stranim jezikom. U drugom dijelu upitnika se od ispitanika tražilo da na 23 tvrdnje uz pomoć Likertove skale procjene s rasponom od 1 (uopće se ne slažem) do 5 (u potpunosti se slažem) izraze svoje stavove vezane uz online nastavu.

Prikupljeni podaci su se obradili izračunom relativnih frekvencija. Dobiveni rezultati prikazani su strukturnim krugovima i jednostavnim položenim stupcima, a potom u tekstu i interpretirani.

\subsection{Rezultati istraživanja}

Rezultati istraživanja prikazani su strukturnim krugom i jednostavnim stupcima u kojima su odgovori studenata iskazani postotcima. 
Slika 1. Struktura studenata 2. godine Strojarskog odjela TVZ-a prema stupnju zadovoljstva izvođenjem online nastave

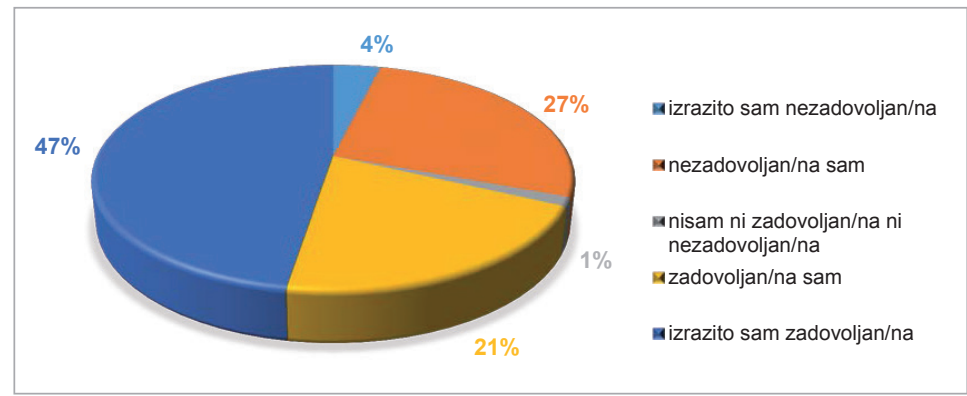

Izvor: vlastito istraživanje

Rezultati istraživanja pokazali su kako je čak dvije trećine studenata zadovoljno izvođenjem online nastave, dok je trećina studenata iskazala svojevrsno nezadovoljstvo.

\section{Slika 2. Distribucija studenata 2. godine Strojarskog odjela TVZ-a prema razlozima} zadovoljstva izvođenjem online nastave

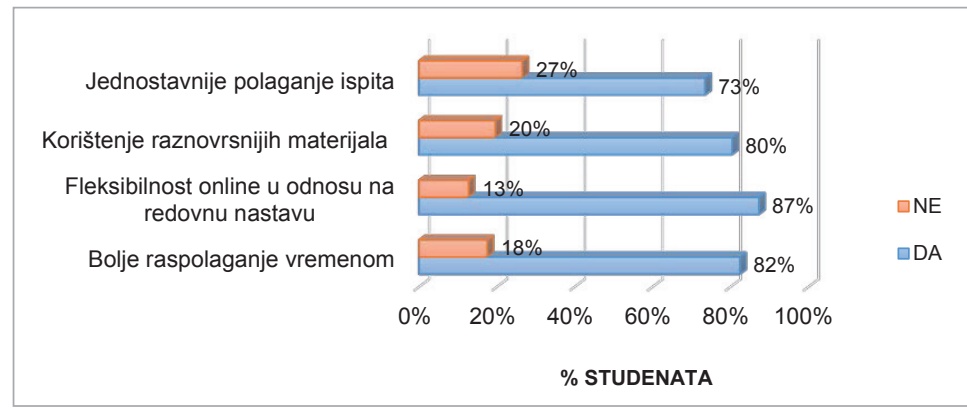

Izvor: vlastito istraživanje

Kada navode razloge zadovoljstva izvođenjem online nastave u prvom redu ističu fleksibilnost u odnosu na tradicionalan način poučavanja, kao i bolje raspolaganje vremenom te korištenje raznovrsnijih materijala. S druge strane, kod načina polaganja ispita, iako su u velikom broju zadovoljni, trećina njih smatra to nedostatkom. 
Slika 3. Distribucija studenata 2. godine Strojarskog odjela TVZ-a prema razlozima nezadovoljstva izvođenjem online nastave

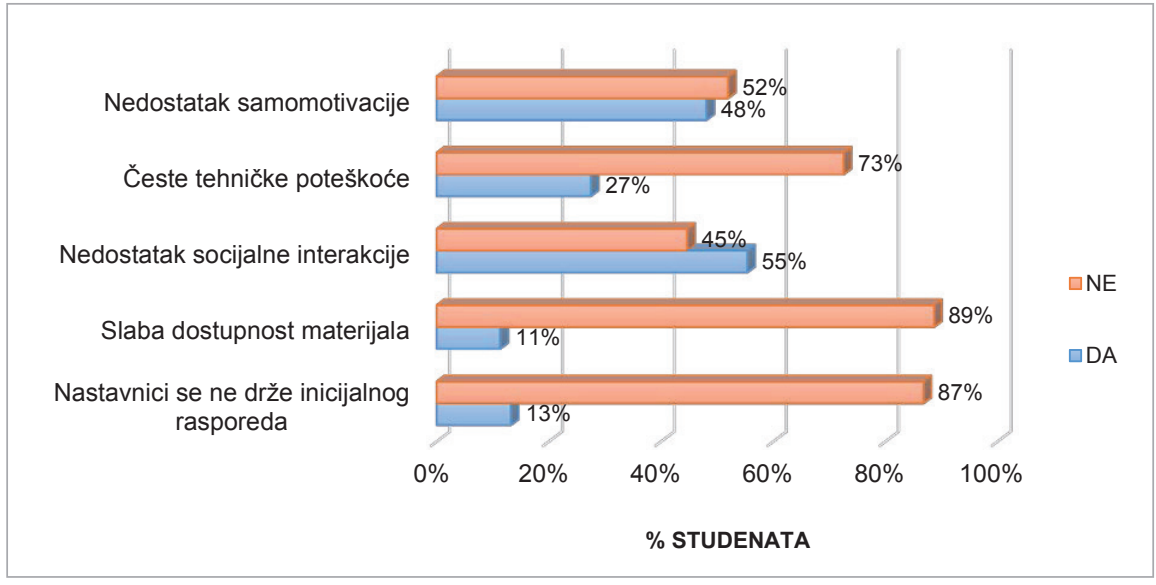

Izvor: vlastito istraživanje

Kao najveće uzroke nezadovoljstva studenti su istaknuli nedostatak socijalne interakcije i samomotivacije. Njih $27 \%$ je imalo tehničkih poteškoća, dok je dostupnost nastavnika i materijala bila zadovoljavajuća i u skladu s potrebama i očekivanjima.

\section{Slika 4. Struktura odgovora studenata 2. godine Strojarskog odjela TVZ-a prema} stupnju težine savladavanja stranog jezika u online nastavi.

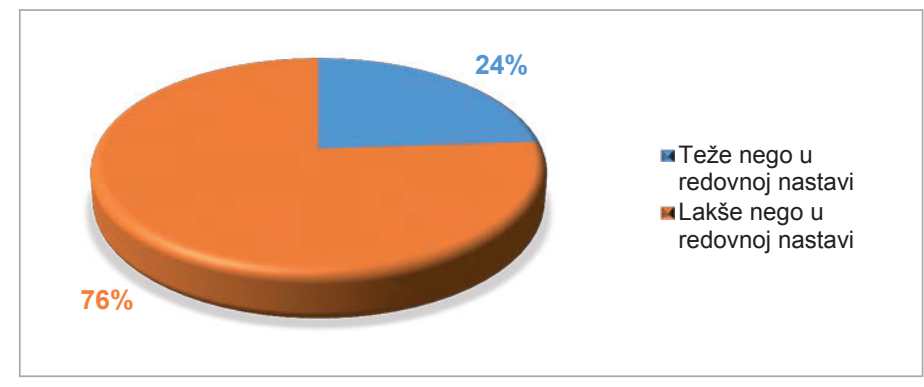

Izvor: vlastito istraživanje

Odgovor na pitanje o stupnju težine savladavanja engleskog jezika u online nastavi studenata je u skladu s općim stavom i navedenim razlozima zadovoljstva što je prikazano u Slici 2. jer se više od dvije trećine izjasnilo da im to lakše činiti online nego na tradicionalnim načinom učenja.

\section{ZAKLJUČAK}

Usprkos činjenici da je neočekivano, nespremno i u jako kratkom vremenu trebalo odgovoriti na kriznu situaciju te se njoj prilagoditi bez umanjivanja dosadašnjih zadanih standarda kvalitete, istraživanje je pokazalo da su se i studenti u tome dobro snašli. U većini 
su iskazali zadovoljstvo poučavanjem, dostupnim materijalima i alatima za provođenje online nastave, što je potvrdilo da je poznavanje, ali i učenje stranih jezika od iznimne važnosti za komunikaciju i stjecanje novih znanja i kompetencija, posebno u godinama neizvjesne budućnosti.

Dosadašnja iskustva, a još će više iskustva u budućnosti doprinijeti jasnijoj slici pozitivne, ali i negativne strane online učenja, razloge zadovoljstva i nezadovoljstva, težine savladavanja pojedinih predmeta kao i mogućnosti unapređivanja online poučavanja koja će odgovarati izazovima u budućnosti. lako je istraživanje provedeno u kratkom vremenu i na relativno malom broju studenata, rezultati pokazuju zadovoljstvo u pristupu poučavanja, unatoč poteškoćama i dodatnim naporima u savladavanju novih metoda i tehnika usvajanja znanja.

S obzirom na neizvjesnu budućnost, pred nama su brojni izazovi na koje treba odgovoriti u praksi, a onda i budućim istraživanjima, imajući u vidu da je sve više onih koji smatraju da će se integracijom informacijske tehnologije u obrazovanju ubrzati razvoj i primjena online metoda, tehnika i alata koje će u kratkom vremenu postati sastavni dio obrazovanja u budućnosti. Međutim još je puno izazova, prvenstveno zbog jaza između razvijenih i nerazvijenih zemalja, kao i jaza unutar zemalja samih jer je neočekivana transformacija dosadašnjih sustava obrazovanja još više naglasila socio-ekonomske razlike i potrebu za jednakim pristupom tehnologiji. 


\title{
SATISFACTION WITH THE CONDUCT OF ONLINE CLASSES AMONG THE STUDENTS OF ZAGREB UNIVERSITY OF APPLIED SCIENCES
}

\author{
Lucija Bačić, PhD, Senior Lecturer \\ Zagreb University of Applied Sciences \\ Vrbik 8, 10 000, Zagreb, Croatia \\ Phone number: +385915364727, e-mail: lucija.bacic@tvz.hr \\ Marija Krstinić, MA \\ Zagreb University of Applied Sciences \\ Vrbik 8, 10 000, Zagreb, Hrvatska \\ Phone number: +385915336380, e-mail: marija.krstinic@tvz.hr
}

\begin{abstract}
The Covid-19 virus epidemic has highlighted the need to discover different methods as well as assess the success of distance learning. Teachers and students around the world have faced perhaps the greatest challenge so far, adapting to the available platforms in a short time and equally embracing both the advantages and disadvantages of virtual teaching. This epidemic has actually widened the gap between those who can access digital learning opportunities and those who are excluded because not everyone has adapted to the situation equally successfully. We must also emphasize that a good online learning experience is not necessarily related to the technology we choose, but to the way teachers and students dedicate themselves to that form of teaching and learning, especially when it comes to learning a foreign language. In this paper, a research was conducted on a sample of 120 full-time and part-time students of the 2nd year of the Mechanical Engineering Department at the Zagreb University of Applied Sciences, in April and May 2020. The objectives of the research are to show the degree of satisfaction or dissatisfaction of the students at the Zagreb University of Applied Sciences as well as to determine the degree of difficulty in mastering a foreign language by online teaching. The research was conducted with a survey questionnaire on the basis of which the calculation of relative frequencies will determine the stated goals.
\end{abstract}

Keywords: online teaching; traditional teaching; learning a foreign language; motivation 


\section{LITERATURA}

1. European Commission. Coronavirus learning resources: online platforms Preuzeto $s$ https:// ec.europa.eu/education/resources-and-tools/coronavirus-online-learning-resources/onlineplatforms_en

2. European Data Portal. (2020.) Education during COVID-19; moving towards e-learning. Preuzeto s https://www.europeandataportal.eu/en/impact-studies/covid-19/education-duringcovid-19-moving-towards-e-learning

3. International Society for Technology in Education. Preuzeto s https://www.iste.org/

4. Perez-Castillejo, S. (2017). Can a Foreign Language be Learned Online? Implications Behind this Question. Preuzeto s https://www.emergingedtech.com/2017/01/can-a-foreign-language-belearned-online-implications-behind-question/

5. World Economic Forum. (2020). The COVID-19 pandemic has changed education forever. This is how. Preuzeto s https://www.weforum.org/agenda/2020/04/coronavirus-education-globalcovid19-online-digital-learning/ 